\title{
HUBUNGAN PELAYANAN DENGAN KEPUTUSAN MENGGUNAKAN JASA PT. ANUGRAH QUBA MANDIRI BENGKULU
}

\author{
Marliadi \\ Ida Anggriani \\ Program Studi Manajemen \\ Fakultas Ekonomi Universitas Dehasen Bengkulu
}

\begin{abstract}
ABSTRAK
Marliadi, Ida Anggriani; Kebutuhan akan jasa tour and travel semakin berkembang pesat belakangan ini. Perusahaan yang bergerak di bidang pelayanan perjalanan wisata/ tour and travel, merupakan perusahaan yang menawarkan jasa kepada kepada masyarakat baik atas nama individu ataupun badan usaha. Untuk mempertahankan eksistensi usaha ditengah persaingan usaha yang semakin kompetitif karena banyaknya bermunculan perusahaanperusahaan sejenis, baik yang berskala nasional maupun internasional, maka setiap perusahaan harus dapat memberikan pelayanan yang baik kepada pengguna jasa ataupun calon pengguna jasa. Tujuan penelitian ini adalah untuk mengetahui Hubungan Pelayanan dengan Keputusan Menggunakan Jasa PT. Anugrah Quba Mandiri Bengkulu. Metode analisis dalam penelitian ini adalah korelasi rank spearman. Dari hasil perhitungan korelasi diperoleh nilai koefisien korelasi spearman rank atau rho hitung $(\rho)$ sebesar 0,71 artinya hubungan antara variabel pelayanan dengan keputusan menggunakan jasa adalah kuat karena berada diantara interval 0,60 - 0,799. Dari Uji hipotesis diperoleh rho hitung 0, 71 artinya lebih besar dari rho tabel $(0,71>0,364)$, dengan demikian hipotesis Ha diterima dan Ho ditolak artinya terdapat hubungan yang signifikan antara Pelayanan dengan Keputusan Menggunakan Jasa PT. Anugrah Quba Mandiri Bengkulu.
\end{abstract}

\begin{abstract}
Marliadi, Ida Anggriani; Companies engaged in travel services/ tours and travel, is a company that offers services to the public good on behalf of an individual or business entity.. Effort to maintain the existence of competition amid an increasingly competitive due to the large emerging peer companies, both national and international, each company must be able to provide good service to service users or potential users of the service. Objectives to be achieved through this research is to determine the relationship with Decision Services Using Services PT. Anugrah Quba Mandiri Bengkulu. The method of analysis in this study are: a qualitative analysis and quantitative analysis. Obtained from the calculation of correlation Spearman rank correlation coefficient or rho count ( $\rho$ ) of 0.71 means the relationship between the variables of service with the decision to use the services is strong because in between the interval from 0.60 to 0.799 . Testing hypotheses derived from rho count 0,71 means greater than rho table $(0.71>0.364)$, so the hypothesis Ho is rejected and Ha accepted means there is a significant relationship between the Decision Service Using the Services PT. Anugrah Quba Mandiri Bengkulu.
\end{abstract}

\section{Key Word: Services, Buying Decision}

\section{PENDAHULUAN}

Perubahan dan perkembangan dari kemajuan teknologi terutama teknologi informasi menjadikan dunia usaha pada saat ini semakin tajam. Perubahan dan perkembangan teknologi informasi tersebut membawa dampak pada minat dan keputusan pelanggan dalam melakukan keputusan pembelian. Sebelum membeli suatu produk, umumnya konsumen melakukan evaluasi dan pemilihan yang digunakan akan menghasilkan suatu keputusan. Pengambilan keputusan sendiri merupakan sebuah proses yang terdiri dari beberapa tahap, yaitu pengenalan ebutuhan, pencarian informasi, evaluasi altematif sebelum pembelian, pembelian konsumen, 
dan evaluasi altematif sesudah pembelian. Berbagai altenatif pilihan mendapatkan informasi yang dibutuhkan, membuat masyarakat lebih bijak dan leluasa dalam menentukan pilihan pada produk dan jasa yang dianggapnya lebih bermutu dan berkualitas. Dengan demikian terjadi pula persaingan yang semakin ketat diantara perusahaan yang menghasilkan produk atau jasa yang sama.

Pelayanan yang baik merupakan satu kesatuan yang terintegrasi dan bisa dilihat dari ekspektasi pelanggan perusahaan. Perusahaan harus dapat mengembangkan produk yang bersifat memberikan kemudahan, menguntungkan, dan bisa diterima oleh pelanggan. Segala cara ditempuh untuk memenangkan persaingan dengan penciptaan produk andalan yang intinya memberikan pelayanan terbaik terhadap pelanggan dengan tujuan untuk mempertahankan pelanggan lama dan menarik pelanggan baru.

Peningkatan kualitas jasa yang ditawarkan semakin mendapatkan banyak perhatian bagi perusahaan. Hal ini disebabkan karena kualitas jasa dapat digunakan sebagai alat untuk mencapai keunggulan kompetitif. Dengan adanya peningkatan kualitas jasa yang baik maka dapat menimbulkan keputusan pembelian yang pada akhimya akan timbullah loyalitas pelanggan, dan berkemungkinan besar menarik pelanggan baru. Pelanggan yang telah loyal pada suatu jasa juga dapat diartikan bahwa kebutuhan pelanggan tersebut sudah terpuaskan sehingga akan melakukan keputusan pembelian lebih dari sekali.

Hal tersebut sangat menguntungkan perusahaan, karena dengan terpuasnya pelanggan, maka pelanggan tidak akan melirik perusahaan lain dan membuat pelanggan untuk memutuskan pembelian berkali-kali dan tidak ingin berpindah ke perusahaan lain, kemungkinan besar terjadi promosi gratis yang dilakukan oleh pelanggan yang telah loyal dalam bentuk Word of Mouth (WOM) kepada pelanggan lainnya.

Semakin hari persaingan dalam dunia bisnis kian ketat terutama di bidang pelayanan dan jasa, hal ini dapat terlihat dari segi kemunculan usaha yang bergerak di bidang jasa, bersamaan dengan hal tersebut banyak perusahaan jasa yang sudah banyak bermunculan sehingga membuat persaingan semakin lebih ketat. Terkadang banyak perusahaan yang bergerak pada bidang jasa dan pelayanan kurang memperhatikan kepuasan pelanggannya. Sebuah perusahaan yang bergerak pada bidang jasa dan pelayanan harus mengutamakan nilai kepuasan pelanggannya terhadap jasa pelayanan yang telah mereka berikan. Kepuasan pelanggan sangat berpengaruh terhadap kemajuan perusahaan itu sendiri. Karena apabila ada satu saja pelanggan yang merasa tidak terpuaskan maka pelanggan tersebut dapat mempengaruhi calon pelanggan lainnya, oleh karena itu perusahaan yang bergerak pada bidang jasa dan pelayanan khususnya pada perusahaan yang bergerak pada bidang tour and travel harus lebih mengutamakan pelayanan yang baik, baik dari segi keamanan, kenyamanan serta fasilitas-fasilitas yang diberikan oleh perusahaan tersebut yang dapat membuat pelanggan merasa sangat terpuaskan.

Kebutuhan akan jasa tour and travel semakin berkembang pesat belakangan ini. Hampir seluruh penjuru tanah air perusahaan jasa tour and travel ada. Tour and travel sendiri adalah sebuah bentuk perusahaan yang bergerak dalam pelayanan jasa tur baik dalam dan luar negeri.

Perusahaan yang bergerak di bidang pelayanan perjalanan wisata/tour and travel, merupakan perusahaan yang menawarkan jasa kepada kepada masyarakat baik atas nama individu ataupun badan usaha. Untuk mempertahankan eksistensi usaha ditengah persaingan usaha yang semakin kompetitif karena banyaknya bermunculan perusahaan-perusahaan sejenis, baik yang berskala nasional maupun intemasional, maka setiap perusahaan harus dapat memberikan pelayanan yang baik kepada pengguna jasa ataupun calon pengguna jasa.

PT. Anugrah Quba Mandiri Bengkulu merupakan perusahaan yang bergerak dibidang Tour and travel yang khusus untuk perjalanan wisata ibadah seperti haji dan umroh. Masalahmasalah yang dihadapi. PT. Anugrah Quba Mandiri untuk menarik pelangganpun sering terjadi seperti kurangnya pengetahuan bagaimana melakukan pelayanan dan menarik pelanggan untuk memutuskan pembelian jasa, PT Anugrah Quba Mandiri Bengkulu harus mampu menghadapi permasalahan pelayanan dengan baik, dengan terus meningkatkan kualitas pelayanan dan 
bagaimana menghadirkan pelayanan yang baik untuk menarik minat pelanggan untuk melakukan keputusan pembelian jasa kepada PT. Anugrah Quba Mandiri Bengkulu.

Berdasarkan uraian di atas maka peneliti tertarik untuk mengadakan penelitian dengan judul "Hubungan Pelayanan dengan Keputusan Menggunakan Jasa PT. Anugrah Quba Mandiri Bengkulu".

\section{LANDASAN TEORI Pelayanan}

Salah satu bentuk pemasaran yang bersifat khusus adalah pemasaran jasa. Pemasaran jasa memiliki sejumlah perbedaan dengan pemasaran barang yang sudah umum dikenal. Oleh karena itu pengertian pemasaran jasa yang baik perlu didukung dengan pengertian mengenai jasa itu sendiri, aspek-aspek yang menciptakan peluang pemasaran jasa, serta isu-isu strategis yang perlu diperhatikan oleh para penyedia jasa.

Adanya kemajuan perekonomian global dewasa ini mendorong pertumbuhan sektor jasa. Banyak peluang bisnis yang muncul dari sektor ini, demikian pula halnya kesempatan kerja semakin luas. Berbagai bisnis jasa banyak dijumpai dalam hidup kita sehari-hari, diantaranya adalah asuransi, telekomunikasi, pendidikan, reparasi, jasa finansial termasuk perbankan. Itu baru sebagian dari sekian banyak jenis jasa yang berkembang dewasa ini. Bisa kita bayangkan betapa berpengaruhnya bisnis jasa dalam dunia modern. Kini setiap konsumen tidak lagi sekedar membeli suatu produk, tetapi juga segala aspek jasa/pelayanan yang melekat pada produk tersebut, mulai dari tahap prapembelian hingga tahap pembelian.

Sejumlah ahli tentang jasa telah berupaya untuk merumuskan definisi jasa yang konklusif dan beragam. Beberapa definisi yang beragam itu dapat dilihat dalam rumusan berikut ini, seperti Tjiptono (2004: 6) mengatakan bahwa : "Jasa (Services) merupakan aktivitas, manfaat atau kepuasan yang ditawarkan untuk dijual".

Sebenarnya pembedaan secara tegas antara barang dan jasa sering kali sukar dilakukan. Hal ini dikarenakan pembelian suatu barang sering kali disertai dengan jasa-jasa tertentu (misalnya instalasi, perawatan, reparasi, pelatihan dan bimbingan operasional) dan sebaliknya pembelian suatu jasa seringkali juga melibatkan barang-barang yang melengkapinya (misalnya makanan di restoran, telepon dalam jasa telekomunikasi).

Kemudian Kotler dalam Tjiptono (2004: 6) merumuskan jasa sebagai berikut : "Setiap tindakan atau perbuatan yang dapat ditawarkan oleh suatu pihak kepada pihak lain yang pada dasamya bersifat intangible (tidak berwujud fisik) dan tidak menghasilkan kepemilikan sesuatu".

Sedangkan Leonard Berry dalam Yazid (2008: 2) mendefinisikan : "Jasa itu sebagai deeds (tindakan, prosedur, aktivitas), proses-proses dan unjuk kerja yang intangibel". Walaupun demikian menurut pendapat ahli tersebut diatas, wujud jasa bisa juga mencakup laporan akhir yang tangibel, atau berupa materi-materi instruksional yang tangibel seperti pelaksanaan jasa pelatihan (training) karyawan.

Zithami dan Bitner (Yazid, 2008: 6) merumuskan definisi jasa sebagai : "Jasa itu mencakup semua aktivitas ekonomi yang keluarannya bukanlah produk atau konstruksi fisik, yang secara umum konsumsi dan produksinya dilakukan pada waktu yang sama, dan nilai tambah yang diberikannya dalam bentuk (kenyamanan, hiburan, kecepatan dan kesehatan) yang secara prinsip intangibel bagi pembeli pertamanya".

Lovelock (2007: 5) mengemukakan : "Jasa adalah tindakan atau kinerja yang ditawarkan suatu pihak kepada pihak lainnya. Walaupun prosesnya mungkin terkait dengan produk fisik, kinerjanya pada dasamya tidak nyata dan biasanya tidak menghasilkan kepemilikan atas faktor-faktor produksi". Jasa menciptakan manfaat bagi pelanggan dengan mewujudkan perubahan yang diinginkan dalam diri atau atas nama penerima.

Jasa adalah kegiatan yang dapat diidentifikasikan secara tersendiri, pada hakikatnya bersifat tidak teraba, untuk memenuhi kebutuhan dan tidak harus terikat pada penjualan produk atau jasa lain (Mursid, 2003: 116). 
Pelayanan merupakan produk jasa yang diberikan produsen pada konsumen. Sari (2008 : 46) menyatakan bahwa ". Suatu jasa pelayanan atau service adalah setiap kegiatan atau keuntungan yang dapat ditawarkan oleh satu pihak ke pihak lain yang secara esensial tidak nampak (intangible) atau tidak menimbulkan kepemilikan sesuatupun". Berdasarkan definisi diatas istilah produk ini selain terarah pada sesuatu yang bersifat fisik, juga bisa digunakan untuk bersifat non fisik, seperti jasa atau pelayanan. Secara sederhana, istilah service bisa diartikan sebagai melakukan sesuatu bagi orang lain (Tjiptono, 2008: 1).

Sedarmayanti (1999: 95) mengungkapkan bahwa yang dimaksud dengan pelayanan umum adalah "melayani suatu jasa yang dibutuhkan oleh masyarakat dalam segala bidang". Saefullah, (1999: 5) juga menyatakan bahwa "pelayanan umum (public service) adalah pelayanan yang diberikan pada masyarakat umum yang menjadi warga negara atau yang secara sah menjadi penduduk negara yang bersangkutan".

Sugiarto (2002: 36) Pelayanan adalah suatu tindakan yang dilakukan untuk memenuhi kebutuhan orang lain dengan tingkat kepuasan yang hanya dapat dirasakan oleh yang melayani ataupun yang dilayani.

70) yaitu :

5 dimensi faktor utama dalam penentuan indikator pelayanan jasa (Tjiptono, 2004:

1. Tangibles (Tampilan fisik/bukti langsung) : merupakan penampilan dan kemampuan langsung sarana dan prasarana fisik yang meliputi fasilitas fisik perlengkapan, karyawan dan sarana komunikasi.

2. Reliability (keandalan) yaitu kemampuan perusahaan dalam memberikan pelayanan yang dengan segera, akurat dan memuaskan.

3. Responsiveness (daya tanggap), yaitu keinginan para karyawan untuk membantu para pelanggan dan memberikan pelayanan yang tanggap.

4. Assurance (jaminan) mencakup pengetahuan, kemampuan, kesopanan dan sifat dapat dipercaya yang dimiliki karyawan, bebas dari bahaya, resiko atau keragu-raguan.

5. Emphaty (empati) yaitu memberikan perhatian yang bersifat individual atau pribadi secara tulus kepada pelanggan, dan memahami apa yang dibutuhkan oleh pelanggan

Dalam melakukan pelayanan ataupun meningkatkannya harus ada persiapan yang baik menurut Sugiarto (2002:38) bentuk-bentuk persiapan dalam pelayanan adalah sebagai berikut :

1. Persiapan fisik, persiapan fisik sendiri meliputi hal- hal berikut :

a. Berpakaian yang rapi.

b. Menjaga penampilan raut muka yang jemih, segar dan ceria.

c. Penampilan sikap tubuh yang lentur, luwes dan sopan.

d. Tutur kata yang runtut, halus dan santun

e. Menjaga kesehatan jasmani agar selalu prima

2. Persiapan mental, persiapan mental sendiri adalah sebagai berikut:

a. Memelihara konsentrasi agar hanya tertuju kepadatugas dan pekerjaan.

b. Tanamkan rasa percaya diri dan bangga akan tugas.

c. Meninggalkan konflik dan persoalan pribadi.

3. Persiapan alat Bantu.

Alat bantu disini adalah barang atau benda yang secara tidak langsung ikut terpakai pada waktu melayani pelanggan, seperti alat-alat tulis, formulir-formulir yang digunakan dan sebagainya.

Sugiarto (2002: 36) menuliskan tujuan khusus dalam pemberian pelayanan yang baik adapun tujuannya adalah sebagai berikut :

1. Tujuan bagi perusahaan dalam memberikan pelayanan yang baik adalah untuk :
a. Meningkatkan hasil.
b. Menghindari perputaran tenaga kerja.
c. Dapat meningkatkan semangat kerja kepada karyawan.
d. Bisa memberikan motivasi dan kesetiaan karyawan terhadap perusahaan. 
e. Mengikut sertakan karyawan dalam memecahkan masalah-masalah yang dihadapi perusahaan.

f. Mengurangi keluhan - keluhan.

g. Dapat meningkatkan kesejahteraan karyawan dalam hubungan dengan kesejahteraan sosial.

h. Memperbaiki hubungan manusia.

i. Merupakan alat untuk meningkatkan kesejahteraan badaniah dan rohaniah.

j. Memperbaiki kondisi kerja.

k. Menambah perasaan aman.

l. Memperbaiki sikap karyawan yang menguntungkan terhadap pekerjaan dan lingkungan.

2. Tujuan pelayanan bagi karyawan perusahaan.

a. Dapat memberikan kenikmatan melalui fasilitas yang dengan cara lain tidak tersedia.

b. Memberikan kepuasan kerja.

c. Menghindari perasaan tidak aman.

d. Memotivasi keinginan untuk kemajuan perseorangan.

e. Memberikan kesepakatan tambahan untuk memperolehstatus.

f. Memberikan kompensasi tambahan.

3. Bagi masyarakat pengguna layanan

Pelayanan yang mudah ramah, cepat, cermat, tepat waktu serta tidak berbelit-belit yang diberikan oleh suatu peruhaaan merupakan suatu yang esensial bagi masyarakat pengguna layanan yang tidak memungkinkan untuk mendapatkan pelayanan kesejahteraan yang mahal.

\section{Perilaku Pembeli}

Buchari (2011:96) Perilaku pembeli adalah tingkah laku dari konsumen, dimana mereka dapat mengilustrasikan pencarian untuk membeli, menggunakan, mengevaluasi, dan memperbaiki suatu produk dan jasa mereka. Fokus dari perilaku konsumen adalah bagaimana individu membuat keputusan untuk menggunakan sumber daya mereka yang telah tersedia untuk mengkonsumsi suatu barang atau jasa.

Perilaku konsumen adalah proses dan aktivitas ketika seseorang berhubungan dengan pencarian, pemilihan, pembelian, penggunaan, serta pengevaluasian produk dan jasa demi memenuhi kebutuhan dan keinginan. Perilaku konsumen merupakan hal-hal yang mendasari konsumen untuk membuat keputusan pembelian. Untuk barang berharga jual rendah (lowinvolvement) proses pengambilan keputusan dilakukan dengan mudah, sedangkan untuk barang berharga jual tinggi (high-involvement) proses pengambilan keputusan dilakukan dengan pertimbangan yang matang.

Perilaku konsumen adalah tindakan-tindakan yang dilakukan individu, kelompok atau organisasi yang berhubungan dengan proses pengambilan keputusan dalam mendapatkan, menggunakan barang-barang atau jasa ekonomis yang dapat dipengaruhi oleh lingkungan (Swastha, 2003:21). Ada 2 aspek penting dari arti perilaku konsumen :

1. Proses pengambilan keputusan.

2. Kegiatan fisik yang kesemuanya ini melibatkan individu dalam menilai mendapatkan dan mempergunakan barang-barang dan jasa ekonomis.

Mempelajari perilaku konsumen akan memberikan petunjuk bagi pengembangan produk baru, keistimewaan produk, harga, saluran pemasaran, pesan iklan dan elemen bauran pemasaran lainnya. Titik tolak untuk memahami perilaku pembeli adalah rangsangan tanggapan. Rangsangan pemasaran dan lingkungan mulai memasuki kesadaran pembeli. Karakteristik pembeli dan proses pengambilan keputusan menimbulkan keputusan pembelian tertentu. Tugas pemasar adalah memahami apa yang terjadi dalam kesadaran pembeli mulai dari adanya rangsangan dari luar hingga munculnya keputusan pembelian pembeli.

Perilaku konsumen akan menentukan proses pengambilan keputusan dalam pembelian, proses tersebut merupakan sebuah pendekatan penyesuaian masalah yang terdiri 
dari lima tahap yang dilakukan konsumen, kelima tahap tersebut adalah pengenalan masalah, pencarian informasi, penilaian altematif, membuat keputusan, dan perilaku pasca pembelian.

\section{Keputusan Pembelian}

Pemahaman mengenai keputusan pembelian konsumen meliputi bagaimana individu, kelompok dan organisasi memilih, membeli, menggunakan dan tidak menggunakan barang atau jasa. Memahami konsumen tidaklah mudah karena setiap konsumen memutuskan pembelian tertentu yang berbeda-beda dan sangat bervariasi.

Menurut Kotler dalam Teguh dan Ronny (2002:204), Keputusan pembelian merupakan serangkaian proses yang dilalui konsumen dalam memutuskan tindakan pembelian. Kotler (2001:28) mengatakan ada lima proses pengambilan keputusan yang dilalui konsumen dalam melakukan keputusan pembelian adapun diantaranya adalah :

1. Pengenalan Masalah

Proses pembelian dimulai dengan pengenalan masalah atau kebutuhan. Jika kebutuhan diketahui maka konsumen akan serta memahami kebutuhan yang belum perlu segera dipenuhi atau masalah dapat ditunda pemenuhannya, serta kebutuhan yang sama-sama harus segera dipenuhi. Jadi pada tahap inilah proses pembelian itu mulai dilakukan.

2. Pencarian Informatif

Seorang konsumen yang telah mengetahui kebutuhannya dapat atau tidak dapat mencari informasi lebih lanjut jika dorongan kebutuhan itu kuat, jika tidak kuat maka kebutuhan konsumen itu hanya akan menjadi ingatan belaka. Konsumen mungkin melakukan pencarian lebih banyak atau segera aktif mencari informasi yang mendasari kebutuhan ini.

3. Penilaian Altematif

Setelah melakukan pencarian informasi sebanyak mungkin, konsumen menggunakan informasi untuk mengevaluasi beberapa merek altematif dalam satu susunan pilihan.

4. Keputusan Pembelian

Jika keputusan yang diambil adalah membeli, maka pembeli akan menjumpai serangkaian keputusan yang menyangkut jenis pembelian, waktu pembelian, dan cara pembelian. Pada tahap ini konsumen benar-benar membeli produk.

5. Perilaku setelah Membeli

Setelah membeli suatu produk, konsumen akan mengalami beberapa tingkatan kepuasan atau ketidakpuasan yang dirasakan, ada kemungkinan bahwa pembeli memiliki ketidakpuasan setelah melakukan pembelian karena tidak sesuai dengan keinginan atau gambaran sebelumnya, dan lain sebagainya.

Adapun indikator dalam keputusan pembelian menurut Kotler (2001:28) :

1. Kemantapan pada sebuah produk.

2. Kebiasaan dalam membeli produk.

3. Memberikan rekomendasi kepada orang lain.

4. Melakukan pembelian ulang.

Keputusan pembelian merupakan kegiatan individu yang secara langsung terlibat dalam pengambilan keputusan untuk melakukan pembelian terhadap produk yang ditawarkan oleh penjual. Ada tiga tiga aktivitas yang berlangsung dalam proses keputusan pembelian oleh konsumen yaitu (Hahn, 2002:223) :

1. Rutinitas konsumen dalam melakukan pembelian.

2. Kualitas yang diperoleh dari suatu keputusan pembelian.

Komitmen atau loyalitas konsumen untuk tidak akan mengganti keputusan yang sudah biasa di beli dengan produk pesaing. 


\section{KERANGKA ANALISIS}

\begin{tabular}{|l|l|}
\hline Pelayanan $(\mathrm{X}):$ & $\begin{array}{l}\text { Keputusan menggunakan jasa (Y) : } \\
\text { 1. Tangible } \\
\text { 2. Realibility } \\
\text { 3. Responsiveness } \\
\begin{array}{l}\text { 4. Assurance } \\
\text { 5. Emphathy }\end{array}\end{array} \quad \begin{array}{l}\text { a. Kemantapan pada sebuah produk. } \\
\text { b. Kebiasaan dalam membeli } \\
\text { produk. } \\
\text { c. Memberikan rekomendasi kepada } \\
\text { orang lain. } \\
\text { d. Melakukan pembelian ulang }\end{array}$ \\
\hline
\end{tabular}

Gambar 1. Kerangka Analisis

\section{Hipotesis}

Dalam penelitian ini, hipotesis yang diajukan adalah diduga: Kualitas pelayanan mempunyai hubungan signifikan dengan keputusan menggunakan jasa PT. Anugrah Quba Mandiri Bengkulu.

\section{HASIL PENELITIAN DAN PEMBAHASAN}

Berdasarkan hasil penelitian tentang pelayanan yang diberikan oleh PT. Anugrah Quba Mandiri Bengkulu dengan lima indikator adalah tangible, reability, responsiveness, assurance dan empaty dan hubungannya dengan Keputusan Menggunakan Jasa, diuraikan sebagai berikut:

a. Pelayanan pada PT. Anugrah Quba Mandiri Bengkulu.

Persepsi responden terhadap pelayanan yang diberikan oleh PT. Anugrah Quba Mandiri Bengkulu kepada pengguna jasa dengan rata-rata adalah 3,79 termasuk pada interval 3,414,20 dengan kriteria baik, artinya pelayanan yang diberikan kepada pengguna jasa pada PT. Anugrah Quba Mandiri Bengkulu mendapat tanggapan yang baik, meskipun demikian PT. Anugrah Quba Mandiri Bengkulu harus meningkatkan pelayanan lagi agar pengguna jasa pada PT. Anugrah Quba Mandiri Bengkulu merasa lebih puas dan semakin yakin dalam memutuskan menggunakan jasa yang disediakan oleh pada PT. Anugrah Quba Mandiri Bengkulu.

Berikut ini akan dijabarkan tentang persepsi responden terhadap pelayanan yang diterima oleh pengguna jasa saat menggunakan jasa PT. Anugrah Quba Mandiri Bengkulu :

1. Karyawan pada PT. Anugrah Quba Mandiri Bengkulu memiliki kemampuan menjelaskan produk dengan baik dan jelas kepada pelanggan, ada pada rata-rata 3,97 dengan kriteria baik, ini artinya karyawan PT. Anugrah Quba Mandiri Bengkulu telah menjalankan tugasnya dengan menjelaskan apa saja keunggulan PT. Anugrah Quba Mandiri Bengkulu dengan baik dan dapat dimengerti baik oleh calon pengguna jasa maupun pengguna jasa PT. Anugrah Quba Mandiri Bengkulu.

2. Pelaksanaan pelayanan atau transaksi yang cepat oleh karyawan pada PT. Anugrah Quba Mandiri Bengkulu, ada pada rata-rata 3,87 dengan kriteria jawaban responden dalam keadaan baik, maka dapat diartikan bahwa karyawan melaksnakan transaksi dengan cepat kepada para pengguna jasa yang menggunakan jasa yang disediakan PT. Anugrah Quba Mandiri Bengkulu.

3. Kecepatan karyawan pada PT. Anugrah Quba Mandiri Bengkulu dalam memahami apa yang dibutuhkan pelanggan, ada pada rata-rata 3,80 dalam kriteria baikini artinya pengguna jasa merasakan bahwa karyawan pada PT. Anugrah Quba Mandiri Bengkulu cepat dalam memahami apa yang diharapkan oleh calon pengguna jasa maupun pengguna jasa yang disediakan oleh PT. Anugrah Quba Mandiri Bengkulu. 
4. Karyawan pada PT. Anugrah Quba Mandiri Bengkulu menyelesaikan pelayanan dengan baik, dalam keadaan baik dengan rata-rata 3,90, artinya karyawan mampu dalam menyelesaikan segala tugas pelayanan dengan baik.

5. Karyawan pada PT. Anugrah Quba Mandiri Bengkulu berlaku ramah dan sopan kepada pelanggan dalam memberikan pelayanan, ada pada rata-rata jawaban responden yaitu 3,83 dengan kriteria baik, ini artinya pengguna jasa maupun calon pengguna jasa pada PT. Anugrah Quba Mandiri Bengkulu merasakan bahwa karyawan PT. Anugrah Quba Mandiri Bengkulu telah berlaku ramah dan sopan dalam setiap pelayanan yang diberikan dan dibutuhkan oleh pengguna jasa maupun calon pengguna jasa pada PT. Anugrah Quba Mandiri Bengkulu.

6. Karyawan pada PT. Anugrah Quba Mandiri Bengkulu memberikan informasi yang dibutuhkan pelanggan dengan baik dan menyenangkan, dengan rata-rata jawaban responden yaitu 4,00 atau dengan kriteria jawaban baik, ini artinya karyawan PT. Anugrah Quba Mandiri Bengkulu mampu menjelaskan dan memberikan informasi dengan baik dan benar dan dapat dimengerti oleh calon pengguna jasa maupun pengguna jasa yang disediakan oleh PT. Anugrah Quba Mandiri Bengkulu.

7. Pelayanan yang diberikan karyawan pada PT. Anugrah Quba Mandiri Bengkulu jelas dan tidak berbelit-belit kepada pelanggan, dengan rata-rata 3,90 dengan kriteria jawaban responden dalam keadaan baik, artinya pelayanan oleh karyawan terhadap pengguna jasa maupun calon pengguna jasa yang disediakan oleh PT. Anugrah Quba Mandiri Bengkulu tidak berbelit-belit dan membuat calon pengguna jasa maupun pengguna jasa dapat langsung mengerti dan tidak merasa pelayanan yang diberikan sangat sulit untuk dijalankan.

8. Karyawan pada PT. Anugrah Quba Mandiri Bengkulu mempunyai pengetahuan yang luas dalam memberikan jawaban yang diberikan oleh pelanggan, ada pada rata-rata 4,00 dan dengan kriteria jawaban responden dalam keadaan baik, ini artinya karyawan sudah memiliki pengetahuan yang cukup luas, tetapi perlu ada peningkatan pengetahuan pada karyawan supaya tanggapan responden lebih baik lagi atas pelayanan yang diberikan.

9. Karyawan pada PT. Anugrah Quba Mandiri Bengkulu memberikan kesamaan pelayanan dan tidak ada diskriminasi terhadap pelanggan/masyarakat, ada pada rata-rata 3,87 dan dalam keadaan baik, artinya calon pengguna jasa maupun pengguna jasa yang disediakan oleh PT. Anugrah Quba Mandiri Bengkulu telah memberikan kesamaan hak kepada tiap-tiap pengguna jasa maupun calon pengguna jasa tanpa adanya diskriminasi dan membuat para pengguna jasa maupun calon pengguna jasa merasa pelayanan yang diberikan tidak adil.

10. Karyawan pada PT. Anugrah Quba Mandiri Bengkulu menjaga kebersihan dan kerapian dalam pelayanan kepada pelanggan, ada pada rata-rata 3,83 dalam keadaan baik, artinya calon pengguna jasa ataupun pengguna jasa yang disediakan oleh PT. Anugrah Quba Mandiri Bengkulu merasakan bahwa karyawan menjaga kerapian pada saat melayani pengguna jasa maupun calon pengguna jasa PT. Anugrah Quba Mandiri Bengkulu.

b. Mengetahui tingkat keputusan menggunakan jasa terhadap pelayanan pada PT. Anugrah Quba Mandiri Bengkulu adalah penting, ini dikarenakan dengan mengetahui keputusan menggunakan jasa PT. Anugrah Quba Mandiri Bengkulu maka pihak PT. Anugrah Quba Mandiri Bengkulu dapat meningkatkan laju perusahaan lebih baik lagi dari segi pelayanan sehingga dapat menarik pengguna jasa lebih banyak lagi.

Berikut ini tanggapan responden terhadap indikator variabel keputusan menggunakan jasa dari sepuluh pemyataan, sebagai berikut:

1. Menurut saya PT. Anugrah Quba Mandiri Bengkulu adalah tempat yang tepat sebagai perusahaan tour and travel untuk melakukan perjalanan wisata, dengan rata-rata 4,00 dalam keadaan baik, artinya pengguna jasa merasakan bahwa PT. Anugrah Quba Mandiri Bengkulu adalah tempat yang baik sebagai perusahaan tour and travel dalam melakukan perjalanan wisata. 
2. PT. Anugrah Quba Mandiri Bengkulu sebagai altematif utama dalam memenuhi kebutuhan perjalanan wisata, ada pada rata-rata 3,66 dalam kriteria yang baik, artinya pengguna jasa percaya bahwa PT. Anugrah Quba Mandiri Bengkulu dapat membantu memenuhi kebutuhan perjalanan wisata dengan baik.

3. Saya tidak ingin menggunakan perusahaan Tour and Travel lain jika saya hendak melakukan perjalanan wisata ada pada rata-rata 3,69 artinya pengguna jasa memiliki kepercayaan yang baik pada PT. Anugrah Quba Mandiri Bengkulu untuk selalu menggunakan jasa yang disediakan oleh PT. Anugrah Quba Mandiri Bengkulu dan tidak berfikir untuk menggunakan perusahaan jasa perjalanan wisata lainnya.

4. Saya merasa puas atas jasa yang di berikan, ada pada rata-rata 3,75 dalam keadaan baik, artinya pengguna jasa merasakan kepuasan dalam setiap pelayanan jasa yang disajikan oleh PT. Anugrah Quba Mandiri Bengkulu.

5. Saya melakukan seleksi yang ketat dalam menentukan perusahaan tour and travel mana yang akan saya pilih dalam melakukan perjalanan wisata, ada pada rata-rata 3,75 dengan kriteria jawaban responden dalam keadaan baik, artinya sebelum menentukan penggunaan peroduk jasa perjalanan wisata yang tepat pengguna jasa telah menyeleksi perusahaan jasa perjalanan wisata mana yang akan digunakan dalam melakukan perjalanan wisata.

6. Saya selalu selektif dalam memilih produk jasa perjalanan wisata umroh, ada pada ratarata 3,78 dengan kriteria jawaban responden dalam keadaan baik, artinya pengguna jasa yang ingin melakukan perjalanan wisata umroh dan haji melakukan seleksi dengan selektif dan cermat sehingga pada akhimya memutuskan jasa perjalanan haji dan umroh yang disedikan oleh PT. Anugrah Quba Mandiri Bengkulu adalah pilihan yang tepat.

7. Saya memberikan informasi mengenai PT. Anugrah Quba Mandiri Bengkulu kepada orang lain, ada pada rata-rata 3,72 dalam kriteria jawaban responden baik, artinya setelah mengetahui kualitas pelayanan yang diberikan oleh PT. Anugrah Quba Mandiri Bengkulu maka pengguna jasa merasa informasi menganai kualitas pelayanan yang baik dari PT. Anugrah Quba Mandiri Bengkulu haruslah disampaikan kepada yang lain agar setiap calon pengguna jasa perjalanan wisata tidak salah dalam memilih perusahaan jasa perjalanan wisata.

8. Saya merekomendasikan PT. Anugrah Quba Mandiri Bengkulu sebagai salah satu perusahaan yang baik dalam melakukan perjalanan wisata, ada pada rata-rata 3,66 dan dalam keadaan baik, artinya pengguna jasa PT. Anugrah Quba Mandiri Bengkulu telah merekomendasikan PT. Anugrah Quba Mandiri Bengkulusebagai perusahaan jasa perjalanan wisata yang tepat untuk melakukan perjhalanan wisata haji dan umroh.

9. Saya dan keluarga membeli produk jasa yang ditawarkan oleh PT. Anugrah Quba Mandiri tidak hanya sekali, ada pada rata-rata 3,69 dan dalam kriteria jawaban baik, artinya pengguna jasa telah memutuskan menggunakan jasa yang ditawarkan oleh PT. Quba Mandiri Bengkulu untuk melakukan perjalanan wisata.

10. Jika ingin melakukan perjalanan wisata lagi saya akan menggunakan di PT. Anugrah Quba Mandiri Bengkulu, ada pada rata-rata 3,75 dan dalam keadaan baik maka artinya pengguna jasa mantap dalam menggunakan jasa yang disediakan oleh PT. Anugrah Quba Mandiri Bengkulu, dan akan menggunakan jasa dari PT. Anugrah Quba Mandiri Bengkulu lagi jika akan melakukan perjalanan wisata kembali.

Untuk mengetahui hubungan antara pelayanan (X) dengan Keputusan Menggunakan Jasa (Y) PT. Anugrah Quba Mandiri Bengkulu, digunakan korelasi spearman rank.

Dari tabel penolong untuk menghitung koefisien korelasi spearman rank pada diketahui nilai-nilai, sebagai berikut:

$\begin{array}{lll}\sum \mathrm{X} & =1.169 \\ \sum \mathrm{Y} & =1.190 \\ \sum \mathrm{bi}^{2} & =1.310\end{array}$


Selanjutnya nilai-nilai tersebut dianalisis untuk mengetahui hubungan pelayanan dengan Keputusan Menggunakan Jasa pada PT. Anugrah Quba Mandiri Bengkulu, sebagai berikut:

$$
\begin{aligned}
& \rho=1-\frac{6 \sum b_{i}{ }^{2}}{n\left(n^{2}-1\right)} \\
& \rho=1-\frac{6 \times 1310}{30\left(30^{2}-1\right)} \\
& \rho=1-\frac{7860}{30 \times 899} \\
& \rho=1-\frac{7860}{26970} \\
& \rho=1-0,29 \\
& \rho=0,71
\end{aligned}
$$

Dari hasil perhitungan di atas diperoleh nilai koefisien korelasi spearman rank atau rho hitung $(\rho)$ sebesar 0,71 dan rho tabel dengan level of significant $95 \%$ dan taraf kesalahan $5 \%$ pada $\mathrm{n}=30$, adalah sebesar 0,364. Dari nilai tersebut diketahui bahwa rho hitung lebih besar dari rho tabel $(0,71>0,364)$, maka Ha diterima dan Ho ditolak artinya terdapat hubungan yang signifikan antara pelayanan terhadap Keputusan Menggunakan Jasa, ini menunjukkan bahwa pelayanan yang baik dan berkualitas sangat memegang peranan penting dalam menentukan Keputusan Menggunakan Jasa kepada PT. Anugrah Quba Mandiri Bengkulu atau tidak, dan jika pelayanan yang dirasa oleh pengguna jasa baik maka perusahaan akan lebih mudah untuk berkembang menjadi perusahaan yang dipercaya oleh masyarakat dalam pelayanan jasa travel haji dan umroh yang disediakan oleh PT. Anugrah Quba Mandiri Bengkulu.

PT. Anugrah Quba Mandiri merupakan perusahaan yang bergerak dibidang tour dan travel, didirikan dengan tujuan memberikan kemudahan dan pelayanan istimewa kepada para jama'ah untuk melaksanakan ibadah haji dan umroh, serta memberikan pelayanan pelanggan untuk paket pariwisata domestik dan intemasional dan menjadi salah satu perusahaan resmi yang bergerak dalam bidang pemberangkatan haji plus dan umroh di kota Bengkulu, sehingga memiliki peluang yang sangat besar untuk maju dan berkembang.

Hasil penelitian menunjukkan bahwa pelayanan PT. Anugrah Quba Mandiri Bengkulu baik sehingga pengguna jasa merasa puas karena harapan pengguna jasa terpenuhi sehingga akan tetap menggunakan produk jasa yang ditawarkan oleh PT. Anugrah Quba Mandiri Bengkulu dalam melakukan perjalanan wisata haji dan umroh.

Hal ini sejalan dengan penelitian yang dilakukan Goesth dan Davis yang dikutip Tjiptono (2004:51) mengemukakan bahwa kualitas diartikan "sebagai suatu kondisi dinamis dimana yang berhubungan dengan produk, jasa, manusia, proses dan lingkungan yang memenuhi atau melebihi harapan.

\section{Kesimpulan}

Dari hasil penelitian dan pembahasan dapat di tarik beberapa kesimpulan:

1. Pelayanan PT. Anugrah Quba Mandiri Bengkulu yang diukur dengan lima dimensi kualitas pelayanan, yaitu tangible, reability, responsiveness, assurance dan empaty diperoleh persepsi dari responden dengan skor 3,90 berada pada interval 3,41-4,20 dengan kriteria baik.

2. Keputusan menggunakan jasa PT. Anugrah Quba Mandiri Bengkulu yang diukur dari Indikator keputusan pembelian adalah kemantapan pada sebuah produk, kebiasaan dalam membeli produk, menberikan rekomendasi kepada orang lain, dan melakukan pembelian ulang diperoleh persepsi responden dengan skor 3,97 berada pada interval 3,41-4,20 dengan kriteria baik.

3. Analisis korelasi spearman rank diperoleh rho hitung lebih besar dari rho tabel $(0,71>$ 0,364), dengan hipotesis Ha diterima dan Ho ditolak artinya terdapat hubungan yang 
signifikan antara pelayanan dengan Keputusan menggunakan jasa PT. Anugrah Quba Mandiri Bengkulu.

4. Dari persepsi responden terhadap indikator penelitian baik variabel pelayanan maupun Keputusan Menggunakan Jasa, menunjukkan bahwa semakin baik pelayanan yang diberikan oleh PT. Anugrah Quba Mandiri Bengkulu kepada seluruh pengguna jasa PT. Anugrah Quba Mandiri Bengkulu, maka akan semakin besar tingkat Keputusan Menggunakan Jasa oleh pengguna jasa atas jasa yang ditawarkan oleh PT. Anugrah Quba Mandiri Bengkulu.

\section{Saran}

Peneliti menyarankan bahwa pelayanan untuk lebih diperhatikan dan ditingkatkan sehingga semua dimensi pelayanan dapat ditanggapi dengan baik sehingga nasabah puas dengan pelayanan yang diberikan, diantaranya peningkatan kecepatan karyawan pada PT. Anugrah Quba Mandiri dalam memahami apa yang dibutuhkan pelanggan, kemudahan prosedur serta peningkatan fasilitas pelayanan yang lebih baik lagi.

\section{DAFTAR PUSTAKA}

Batinggi, Ahmad. 2003. Manajemen Pelayanan Umum. Bahan Kuliah STIA LAN.

Buchari, Alma. 2011. Manajemen Pemasaran dan Pemasaran Jasa. Bandung: Alfabeta.

Hahn, Fred E. 2002. Beriklan dan Berpromosi Sendiri. Jakarta: PT. Gramedia. Pustaka Utama.

Kartasasmita, Ginandjar. 2010. Mengukur kinerja pelayanan dan kepuasan konsumen, Bandung: Pustaka Reka Cipta.

Kotler, Philip. 2001. Manajemen Pemasaran 1. Edisi keduabelas. Jakarta: PT Indeks.

Lovelock, Christopher. 2007. Manajemen Pemasaran Jasa. Jakarta: Indeks.

Mursid, 2003. Manajemen Pemasaran. Jakarta: Bumi Aksara.

Sari, Irine Diana, 2008, Manajemen Pemasaran Usaha Kesehatan Jakarta: Mitra Cendikia.

Saefullah. 1999. Konsep dan Metode Pelayanan Umum yang Baik, dalam Jurnal Ilmu Sosial dan Ilmu Politik. Sumedang: Fisip UNPAD.

Sedarmayanti, 1999. Sumber Daya Manusia dan Produktivitas Kerja. Bandung: Mandar Maju.

Sugiarto. 2002. Psikologi Pelayanan Dalam Industri Jasa. Jakarta: PT Gramedia Pustaka Utama.

Sugiyono, 2009. Metode Penelitian Kunatitatif Kualitatif. Bandung: Alfabeta.

Supranto, J. 2000, Statistik Teori dan Aplikasi, Jakarta: Erlangga.

Suryabrata, sumadi. 2009. Metodologi Penelitian. Jakarta: Rajawali Pers.

Swastha, Basu. 2003. Azas-Azas Marketing, Edisi 3. Yogyakarta: Liberty.

Teguh, Hendra dan A Rusly, Ronny, 2002. Manajemen Pemasaran. Jakarta: PT Prenhallinda.

Tjiptono, Fandy, 2004. Manajemen Pemasaran Jasa. Malang: Bayumedia Publishing. 
Triguno. 2007. Budaya Kerja, Menciptakan Lingkungan Yang Kondusif Untuk Meningkatkan Produktivitas Kerja. Jakarta: Golden Teravon Press.

Yazid. 2008. Pemasaran Jasa. Yogyakarta : Ekonisia. 